\title{
THE UTILIZATION OF FOREST PRODUCTS
}

\author{
By G. C. PICHE
}

$T^{N}$ recent years, our forest industries have met with serious reverses which, on account of their persistency and disastrous effects, have necessitated important changes in the administration of the timberlands owned or leased by these companies.

If it is true that, during the last twenty years, we had the satisfaction to notice real improvements made in the technical direction of the forest affairs of our lumbermen, who decided finally one after the other to venture into forestry, to hire several forest engineers, to have extensive and expensive surveys made of their forest holdings, even to begin some research work, to undertake reforestation and to maintain large nurseries, who contributed jointly to subsidize a large forest products laboratory in Montreal, who gave endowments to universities for the teaching of sylviculture, we have now the regret to find, that following the events which are shaking the financial structure of their corporations, they are compelled to take radical measures which may affect not only the number and the salary of their personnel (employees and working men) but also the forest improvement works of which we were so proud, the number of foresters will be reduced to a minimum, forest researches are almost abandoned, reforestation stopped indefinitely and even nurseries are threatened to be closed forever, unless a good genius will interfere.

We are facing such a disturbance that I have thought advisable to discuss, between ourselves, this distressing problem, in order to find how this professional body of forest engineers can help to the prompt and permanent restoration of the forest policy and practice which seems in danger of falling so much backwards.

First of all, we must admit that the reforms recognized by the various operators are somewhat justified. The state of their finances is indeed precarious, whereas the prospects of improvement seem to be more remote than near. All the attempts to keep together the various elements interested have failed repeatedly. There is always talk of an impending merger, but it means the amalgamation of so many diversified interests that it is very difficult to accomplish it without the sacrifice of some interests. We hope this reorganization will soon take place. It is unquestionable that the concentration of interests, under the same direction, will not only mean a prompt and decisive solution of this gordian knot, but will enable the industry to diversify its production with greater advantage than before.

We must also admit that the crisis which prevails here and in the United States is also affecting Europe very badly. Thus, we find that, recently in 
Sweden, numerous forest companies were also compelled to merge their interests in order to weather the storm and reduce their general and operating expenses as much as possible.

Here our companies have begun to practice severe economy, they are shutting down completely the most expensive mills to operate and they have also reduced by a large percentage the salaries of the high officials and superior employes. But there are savings which are often more expensive than the disbursements to maintain the machine or the plant in operation, and this is particularly true of forest works. In fact, it does not take long before the apparent savings realized are fully obliterated by the spontaneous growth that springs immediately the moment it is not held in check by weedings or thinnings.

All these reforms will certainly lower the cost price of paper and of lumber, but not enough yet to make a sufficient profit at prevailing prices. Of course, the increase in our capacity of production, caused by the creation of new mills and the enlargement of existing units, is not altogether finished, notwithstanding the efforts made to put a halt to it. The overproduction, combined with a falling off in the demand for newsprint, does not allow the paper industry to operate its mills now at more than $60 \%$ of their rated capacity. Until their output is brought up to $80 \%$, we cannot expect the industry to work normally and profitably, of course, provided satisfactory prices are paid.

It is evident that our forest industries cannot survive by following beaten tracks; we must secure new outlets for their productions, which can be obtained either by making new goods or by penetrating into new markets. It is well known that the world's markets are today closely watched by every progressive nation who maintains a body of active and aggressive commercial agents and trade commissioners, who follow keenly the economical developments taking place in every country. You have only to consult the admirable "Commerce Reports," of the United States Department of Commerce, and also our own "Intelligence Trade Reports," to see how well posted must be the trader who desires to sell his goods outside of his country.

You have only to study the returns of our external trade in paper and lumber, to see how hard it is to maintain an even amount of trade with any country. These fluctuations are so great, from year to year, that in many cases, it seems very difficult to expect a sufficient readjustment from our overseas exportations. Therefore I believe the real solution rests in the manufacturing of new products.

I know a firm that has made its policy to venture always into new fields of fabrication and this well in advance of its competitors. The farmer who sells his crop in the early part of the season generally obtains better prices than those farmers who come in later to dispose of their goods. Thus, a forest 
producer should be the first to sell new wood products, so as to get all the profits he can obtain, when the time is favourable. The Brown Corporation, to whom I referred a moment ago, has been a real pioneer in wood utilization. They are still leading and are making good, notwithstanding the crisis. They sold newsprint about the first; but when the prices lowered, on account of increasing production, they soon got out of it to sell rayon pulp, conduits, etc. Today they are even making artificial leather. They have under investigation several processes for various new articles which they will only adopt when they can produce these goods at a profitable price. The firm of Price Brothers \& $\mathrm{Co}$., have also begun research work under the able direction of Dr. Bates and they have already been able to produce a new pulp board, which is a good seller, not only in Canada but also in South America.

All the research men of the world are working energetically to free their country of any commercial dependence, whilst the leaders of Russia, temporarily deprived of financial means, are disposed to sacrifice everything, even the health and the lives of their countrymen, to conquer commercial supremacy and they have started to dump systematically their products at very low prices in order to obtain the funds to build up papermills and sawmills, to develop hydroelectric powers, to extend their railroads, etc., and specially to spread their pernicious doctrines of Bolshevism.

The forest problems of today are of such an order, they have such an influence on the future activities of any nation, that every forester should study them very carefully.

Let us now review what we forest engineers have done to improve the situation. During the last twenty-five years we have spent most of our time in propaganda work, preaching the gospel of fire protection, of the employment of technical foresters, we insisted also upon the necessity of definite soil classification, of reforesting the waste lands and upon the making of an inventory of our forest resources. After all, this missionary campaign has been fruitful, since, in each province, we now find an organized forest service, since the protection of our forests against fires has made progresses since lumbering operations are better supervised, and, in some quarters, the annual cut is now limited to the annual net increment of the forest; and since in many instances, the lumbering waste has been much reduced. Real forest inventories and studies are now being carried on all over Canada. As we know better the real situation of our forests, it appears they are not as badly affected or reduced in volume as we had reasons to fear, on account of the great disasters which have affected them periodically. But it is also evident that their exploitation will, in numerous cases, be rather onerous on account of the relative remoteness of the sectors to cut and of the small sizes of the trees found in the upper basins. In time of crisis, this is a great handicap. But our forest situation is not without issue. We can yet with proper care, 
and with the necessary measures, improve the wealth of our forest stands and thereby reduce considerably the future cost price of wood. I have the conviction that, if the foresters were given a free hand, the necessary funds and powers, the future of our forests can be assured indefinitely.

This is not the first crisis that has hit our forest industries. Other crisis have also occurred in the past, at various intervals, some of them lasting sev. eral years. In fact, whenever there is a general trade depression, every branch of the industry is also affected.

The first lumber crisis of which we have a definite record is that of 1846; and the present one has begun in 1922 for the lumber trade and in 1928 for the paper industry. It is the longest but, like everything human, it will forcibly end. Other crisis are bound to take place sooner or later. We should prepare ouselves against the return of such contingencies. This is why I believe we should decide what are the technical works the government and forest companies should undertake together or separately for the proper administration of our forests, and this without any danger of interruption nor of discontinuance.

In the case of private properties, the owner is the indisputable master of what studies and improvements he desires to have made; as we have yet no law limiting the volume and manner of cutting operations on private forests, this group has to be ignored in the present discussion.

But, in regard to timber limits the question is absolutely different. Fortunately for the nation, the government of each province, in Eastern Canada, controls yet most of the remaining forests. In Quebec, some 51,671,680 acres are under license and $95,242,880$ acres are still vacant, only $7 \%$ of the total forest area is in private control.

The province, being the owner of the soil, should perform all the techni$\mathrm{cal}$ work requiring continuity or permanence, in order to prevent any falling back. If the province had the right to exact from its lessees an inventory of their timber limits, it was because most of them had been leased since several decades in some cases close to a century, therefore many changes had taken place on same, during this long period. These changes were due, either to the cutting operations carried by the limitholder, or to accidents that had $\alpha$ curred during the time of his management; and, this is why he was compelled to assume the burden of this expense, which after all is and should be considered only as a capital expenditure.

Such an inventory was absolutely necessary not only to know the present volume of the forest but also the growing conditions of the stands, so as to place every group of limit under a system of sustained yield. Following each inventory a program of cutting operations and a few methods of treatment judged adequate were devised to carry this policy.

But, for the future technical work, I believe it belongs to the province 
to assume now the burden of the research work necessary to keep the in ventory up to date, i.e., to be able to make, whenever necessary, the revision of the original working plan. Of course, if some inventories are deficient they should be brought up to the standard now accepted by all, at the ex. pense of the limit holder.

In regard to the reforestation of waste lands found on timber limits, the province should supply free the necessary tree seed or the transplants but the limitholder should stand the expense for the judicious use of such material.

Thinnings and improvement cuttings should be carried by limitholders following the plan drafted conjointly by the foresters of the company and of the government.

Yearly lumbering plans made by the limitholder should be examined and discussed on the ground by the foresters of the company and of the govern. ment in order to study the local requirements and decide on the proper method of cutting which will insure proper regeneration in the shortest time possible.

Limitholders should employ foresters to co-operate with government foresters to devise the best methods to lumber their limits in view of improving the future forest stands as much as possible and practicable. I cannot understand a company not having several technical advisers to prepare their forest maps, revise their plans for future cutting operations ordered systematically (according to the age and conditions of each stand), keeping a ledger of the forest stock, studying the requirements of each species and forest type, keeping close watch on the attacks of insects, fungi, etc. (to prevent their spreading, etc.) indeed such men cannot be dispensed with. Our Quebec companies have long ago recognized this need and we have, in our province, more foresters working for private companies than in all the rest of Canada. It may be true that they were primarily employed for the making of inventory but so much work remains to be done in other fields that I cannot understand why some corporations are considering the advisability of reducing their foresters' staff; it should be the contrary, and the only way to save our forests against disasters is to have the right men to look after the technical administration of the forest affairs of the companies and of the country. I hope this tendency will be checked and the progress made in past years will continue to manifest itself everywhere.

Will that be sufficient for the purpose we have in mind? No, for the proper utilization of all the products which the forest can yield directly or indirectly, it will be necessary for the forester to keep himself well posted on all the variations which affect the lumber and paper trades. Let us consider the case of the white pine. Everyone knows that since several years, this wood has been selling with increasing difficulty. If the best grades can still be disposed of, but at a much lower price than heretofore; the poorer grades are very poor sellers and often remain in the yards which they obstruct. Under 
these circumstances, are we going to compel the pine men to remove all logs containing a large percentage of rot? Can we demand that the scaling of defective logs be as severe now, than when these goods were selling with good profit? Who else, but the foresters, should decide upon the intensity of the use of forest products and upon the appreciation of the volume of such products for the payment of dues! If the foresters are not familiar with the market conditions, how can they deal properly with those questions?

Should we not also survey the general conditions affecting the lumber and paper trades in Eastern Canada, instead of limiting our interpretation of the law and regulations to the letter of our statutes and orders in council. All the lumber and paper manufacturers in Ontario, Quebec, New Brunswick and Nova Scotia are competitors on the same markets, their forest products are almost the same, in a word, they have the same problems to solve for the disposition of their goods. Why should not the government of these provinces endeavor to render more uniform the rules and regulations governing the forest operations, so that each manufacturer would be placed on the same footing? We have companies operating in each province, it must represent great hardship to them, in some cases, to face so many different regulations. Already there have been several exchanges of opinion between the administrators of each province on these questions. This year the same reductions of dues were given by Ontario, Quebec, and New Brunswick to help the unemployment. We should work to harmonize our regulations as much as possible. For example, we should have the same ground rent, the same stumpage dues (exception being made for the overbids), the same methods of scaling, the same log rule, the same obligations in regard to the survey of the forest and for the limitation of the volume of the yearly cut to the net increment of the forest. In this way we shall help our captains of industry to work also in common and solve more easily their respective difficulties.

During the last twenty years, the waterpowers in each province have been largely developed, so much so that we have now in Canada, over $6,000,000$ H.P., whereas we had only one tenth of this huge quantity in 1900 . As only one fifth of the potential energy of our total hydraulic powers has yet been developed, it stands to reason that we should carefully consider such projects in order to see how they affect our forests and what help they give us. The regulation of the stream flows has been obtained by the erection of immense storage dams which have flooded large surfaces, and the same may be said of power sites, for the Gouin dam, on the Upper St. Maurice, an area of about 100 square miles was flooded; the Toro dam, on the Mattawin river flooded nearly 30 square miles. The transmission lines, needing cleared right of ways, are also adding to this reduction of wooded surfaces. Not only are we thus affected by the loss of growing material, but the driving of logs across the gigantic artificial lakes thus created add much to the cost of 
wood. However, the abundant production of electrical energy, which can be purchased at a reasonable price, will often cause the creation of a new industry in a remote section of the province. It will certainly induce numerous small factories to start closer to their source of supply of raw material, so the harm done is somewhat compensated by the advantages it brings along. There is enough reason for the forester to interest himself to this important question of white coal; and, in Quebec, where there is still vast areas of vacant forest lands, we have endeavored whenever possible, to marry together the water power with the forest, i.e., we have leased at the same time the use of these two resources, requiring the lessee to develop the water power and to build, within a certain time, a mill to use the material cut from the forests.

The question of forest labor is one of great interest to us. No government exploitation of the forest is yet practised in Canada, but the day is not far when this should be done to supply small industries that cannot afford to purchase large tracts of forest. In our township reserves, we shall have, before long, several sections that should be cut; and, as there is no local market for these products, we should be able to cut the trees and dispose of the products profitably. All the European foresters are exploiting their forests with great advantage, and we should not be inferior to them. However, in the meantime, we find that the labor in our camps is not of the same quality as before, as the output per man appears to diminish gradually. Moreover, there is much restlessness among the men, as the number of "jumpers" increases yearly. Forest colonies established in the woods would render great services; they would furnish a class of laborers better adapted and fitted for this work; and they would relieve us of the present system of jobbers with camps more or less kept in good hygienic conditions. We should devote much time to improve the situation and the standard of our forest workers, who deserve much attention on our part, as they are our principal helpers. Instead of punishing the men with fines for destroying young growth and for cutting undersize trees, we should educate them to the necessity of preserving the offsprings of the future forest; and I am certain they would understand and follow our advice eagerly. This is a part neglected, which requires our immediate attention.

The tourist business has become a great source of revenue in every province. We should not prevent the access of our forest to the honest travellers and specially to the citizens of our country. They have a right to enjoy the beauties of our mountains, and to benefit of the conditions prevailing in our forests to restore their health and rest their spirits. Therefore, I foresee that, before long, numerous summer colonies and camping resorts will be found in our woods, near our lakes, along our beautiful rivers. Thus another 
source of revenue will be derived from the location of each site and by the sale of fuel for the cooking of food and the heating of each hamlet.

The forester should keep himself well posted on the utilization of wood in the industry. From a survey made by Mr. Charles Lathrop Pack, this view is getting more and more accepted by the profession in the United States, yet it seems still more imperious for the Canadian foresters to know exactly what use can be made of such and such a wood, so that we can be able when one cuts a certain section to require the use of every species found therein. We should also know how and where such wood can be employed. Take the case of aspen or poplar, not long ago, this specie was considered a weed in Eastern Canada, yet it has great possibilities and it is becoming used more and more every year. The same thing took place for swamp spruce, and jack pine, which now are in great demand. Take our hardwoods, their use is greatly limited by the accessibility of the forest and only the best logs are taken out; today with the demand of hardwoods for ties, that can be treated, we are able to replace the disappearing cedar by these woods, which were crowding the forest of the Laurentian hills, to the detriment of our soft woods. intmber the forests, we should consider what means were at their disposition.

Instead of blaming the past lumbermen for the methods they employed to lumber the forests, we should consider what means were at their disposition. After all, if they had not cut these trees, what would have become of them? What would be their present value? We have around grand Lake Victoria great stretches covered with old white pine trees which are decaying; would it not have been better to $\log$ them when they were in their prime? Therefore we should be on the alert to have every species of trees in our forest used whenever there is a good demand for it. Red pine is again in great demand; formerly it was for masts, now it is for poles, let us sell as much red pine poles as possible, and let us raise in our nurseries large quantities of this valuable species, which is more immune to insects and diseases than our white pine.

We must not overlook the fact that the forest industry has transformed itself greatly during the last century, and I am sure that a still greater transformation will take place in the near future. Thus, we have seen the end, about 1900 , of the square timber industry; that of wooden ships seems gone for ever, and it was the same for the potash and perlash industry. The overproduction of paper mills will certainly cause most of the great companies to venture into new projects. Many new uses are being found for cellulose products, so much so that Dr. Compton recently was predicting that this century will be called the age of Cellulose. Our chemists will extract from the wood substance as many products as they were able to extract from coal, with so much profit. For the same reason, the efforts to incraese the durability of wood, when in use, will certainly cause a reaction in favor of tim. 
ber for culverts, bridge works, for foundations, etc. With the impregnation of additional substances than the preservative liquids, processes will be perfected to render the wood substance not only waterproof and fireproof, but full artificial coloration of the mass will also be permanently obtained. A process will be soon invented to incorporate a metal structure in the body of objects made from pulp, so we can again see wood trusses competing with structures of steel. We shall also see every part of the tree used, and a greater attention will be given to the elimination of any waste of material either in the forest or at the mill, as every bit of woody material will be in great demand.

The discoveries made in the artificial textile industry justify me to claim that we shall soon manufacture not only artificial silk or wool but that someday we will obtain from the wood of our Canadian trees, a cotton substance that will compete favorably with that grown in the fields and which will be much cheaper.

The experiments we are making with charcoal lead us to believe that we shall not be dependent very long on gasoline for the operation of our motors, either for the traction of vehicles or for the generation of power. I hope to see before long our farmers and our forest colonists using charcoal to operate motors to saw their wood, to pump their water, to generate electricity, etc.

Our lumber goods suffer too much of the competition of lumber drawn from the outside that we can remain indifferent to the numerous questions which must be disposed by our lumbermen. We must therefore not only be familiar with the extent of our forest resources but also know what are the resources of our competitors. With the modern means of transportation, the movement of lumber or of paper is no more limited to the boundaries of a province or even of a country (last year each lumber car circulating in the United States travelled over 750 miles in average). The combination of water and rail transportation also increases the intensity of competition. With the Panama Canal, the operators on the Pacific Coast are now able to deliver their lumber in the Atlantic ports at a price equal to the freight charges to move a car from the Ottawa Valley to the same points. Have we not seen the Russians bringing their lumber and pulpwood into the States, using our St. Lawrence route, our harbours of Sorel and Trois-Rivieres to tranship their goods into New York State, in direct competition with our own lumber and with our own pulpwood. What has been the effect of this importation, in 1930, from Russia, of $60,000,000 \mathrm{ft}$. of lumber and 150,000 cords of pulpwood on markets already disturbed by the crisis! Can we ignore such things? Can I also forget that, in almost every village of Quebec, Dougals fir is now sold at a price to compete with the home product? We are fighting the invasion of Russian woods and we are also taking means to protect our local sawmill man to dispose of his wood profitably and we shall lose no occasion 
to protect our home industry against any invasion. Charity begins at home, and we shall practice this noble virtue.

In regard to the manufacture of paper, can we overlook the fact that, before long, South America and even Australia will manufacture all the printing paper they require by using their indigenous woods for that purpose? Have we not a right to fear that, before long, the radio and television manufacturers will offer subscriptions for the regular delivery of news in the home, in the office, in any large hall, at a fair price, and that it will mean a big slump in the production of newspaper and of course in the consumption of newsprint?

We must seek new outlets for our forest products. This is a task to which foresters should participate, if we want to be worthy of our part in this enterprise, and it is not above our strength nor of our preparation. We should not only assume the direction of the logging and driving operations, as they are only the beginning of utilization. Like the mining engineer, we should go to the full limit of the conversion of the forest products. We should be able to operate sawmills, drying kilns, and also any woodworking establishment plants. Today we find several civil engineers who, not satisfied with making plan for any project, have become contractors and they obtain thus a great success. In Europe, all the manufacturers have had a solid technical foundation, why should it be different here? Why should we limit our activities to the preparation of working plans for the forest, to fire protection and to reforestation? Our task is greater, it will be bigger, if we have vision and if we prepare ourselves for it.

In Finland, the State foresters not only exploit the forests but are also operating sawmills and even pulp and papermills. I would not recommend to follow them as far as that, because I believe the State should not enter into industrial work, but foresters who are in private business should consider these contingencies, as they are within the possibilities of their training and of their career. The men directing the sawmills, the papermills, the lumber trade, did not have greater chances to prepare themselves than we foresters. Have we not seen Mr. Ritchie, a woods manager, being placed in charge of the Wayagamac plant and making a success of it? Have we not seen our friend, MacMillan, venturing into the lumber trade, and becoming one of the greatest traders in every market of the world? The intrusion of Douglas fir, in my own province, is mainly due to his activities. Why could we not find, in our ranks, men able to follow these examples or create new ones?

Therefore, I would suggest that each one of our schools of forestry should seriously consider these questions. Forest utilization is one of the greatest subjects that our students should study carefully and I was glad to see the extension given to it in the Yale and Syracuse forest schools. Are not Professor Bryant and Professor Brown recognized as authorities on these subjects? Our 
forest schools should prepare their graduates to become eventually either operators and manufacturers or traders of forest products and I hope they will organize their courses accordingly.

It is only by penetrating in all the spheres where wood is utilized that we can assure real and positive guarantees for the future of our forest industries. We must be familiar with questions of freight rates, of customs duties, of trade exchanges, of transportation problems, so that we can dispose of our products anywhere there is a market for them.

Without claiming for the foresters a share in the administration of the affairs of this country, as some of the other professional organizations have acquired for them, I maintain that we should have the justified ambition not only to administer the growth of our forest lands, that we should be big enough to take charge of their rational exploitation, of the conversion and sale of all the products that be extracted from them.

I do not claim that we foresters will be able to prevent the occurrence of any crisis, but, being obliged to calculate in our working plans for long periods of exploitations, being familiar with the ups and downs of growth caused by numerous factors of reduction, we are somewhat prepared to face these contingencies. Like our trees, that grow slowly but surely, we will not venture too quickly into large developments and we shall always maintain a safe margin of security to prevent the breaking up of our hopes and calcula-. tions.

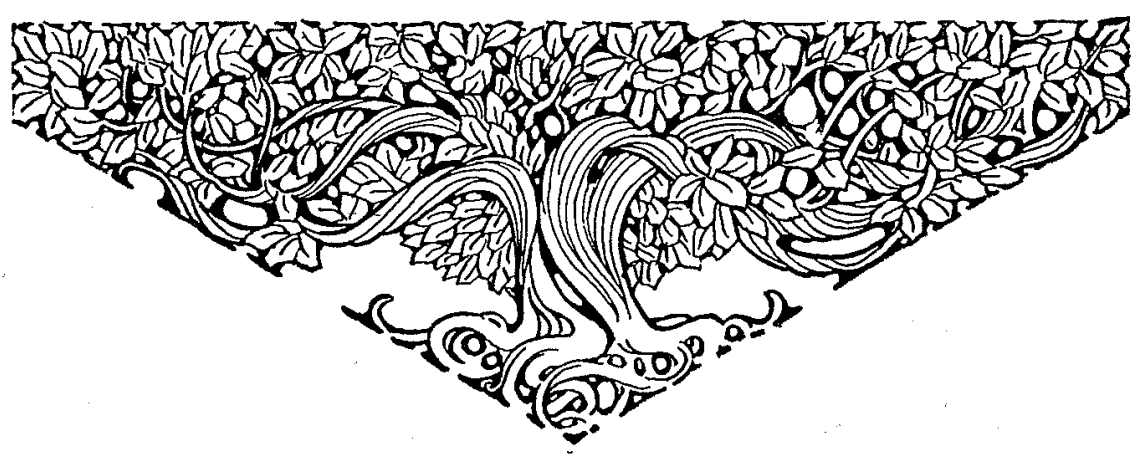

